\title{
Controlled atmosphere and refrigerated storage in cut roses 'Avalanche'(1)
}

\author{
GLÁUCIA MORAES DIAS(2)*, LUCAS OLIVEIRA GOMES SANTOS(2), PATRÍCIA CIA(2), \\ JOSÉ MARIA MONTEIRO SIGRIST(3), SYLVIO LUÍS HONÓRIO(4)
}

\begin{abstract}
In Brazil, there are few studies on cut flowers cold storage, and there is no research on the association of controlled atmosphere with flower cooling. Worldwide research in this sector is considered scarce; this requires the establishment of adequate postharvest technology, involving cold storage and controlled/modified atmosphere for cutting flowers. In Brazil, roses are the most widely cultivated cut flower and a single producer exports three pallets of this species by airfreight per week. The objectives of this work were to define the concentrations of $\mathrm{O}_{2}$ and $\mathrm{CO}_{2}$ in which cut roses 'Avalanche' should be submitted, defining procedures for postharvest conservation and establishing technical guidelines for the exportation of cut roses under controlled atmosphere. The experiments were carried out at $1 \pm 1{ }^{\circ} \mathrm{C}$ with the help of a flowchart to dose the gases, and the concentration of $\mathrm{O}_{2}, \mathrm{CO}_{2}$ and ethylene were assessed. Phase 1 experiment had $\mathrm{O}_{2}$ concentration set at $21 \%$ associated with four different concentrations of $\mathrm{CO}_{2}, 10,20,30$ and $40 \%$. Phase 2 experiment had $\mathrm{O}_{2}$ at $3 \%$ associated with four different concentrations of $\mathrm{CO}_{2}, 3,6,10$ and $15 \%$. The controlled atmosphere with $3 \% \mathrm{O}_{2}$ and $6 \% \mathrm{CO}_{2}$ associated with $1 \pm 1{ }^{\circ} \mathrm{C}$ was indicated for the storage of cut rose 'Avalanche'.
\end{abstract}

Keywords: carbon dioxide, oxygen, postharvest, flowboard.

\section{RESUMO}

\section{Atmosfera modificada em armazenamento refrigerado de hastes de rosas 'Avalanche'}

No Brasil, existem poucos estudos com armazenamento refrigerado e flores de corte, tal como refrigeração associada à atmosfera modificada para flores. Em nível mundial, as pesquisas neste setor são consideradas incipientes; portanto, o estabelecimento de tecnologia de pós-colheita adequada de armazenamento sob refrigeração e atmosfera modificada controlada para flores de corte se faz necessário. No Brasil a rosa é a flor de corte mais cultivada pelos produtores, de forma que apenas um único produtor desta flor exporta até 3 paletes aéreos por semana. Assim, com a hipótese de que a rosa, após o corte, armazenada em ambiente refrigerado e com atmosfera modificada controlada deverá ter sua vida útil ampliada. Os objetivos deste trabalho foram: definir as concentrações de gases nas quais as rosas seriam submetidas em atmosfera controlada; definir procedimentos de pós-colheita para conservação de rosas em combinação com sistema de atmosfera controlada e estabelecer procedimentos técnicos para exportação de rosas sob atmosfera controlada. As análises foram realizadas à temperatura ambiente de $1 \pm 1{ }^{\circ} \mathrm{C}$, e as concentrações de $\mathrm{O}_{2}$ e $\mathrm{CO}_{2}$ e a produção de etileno foram mensuradas. As rosas foram mantidas em armazenamento refrigerado e atmosfera controlada na temperatura de $1 \pm 1^{\circ} \mathrm{C}$. Primeiramente, a concentração de $\mathrm{O}_{2}$ foi fixada em $21 \%$ e quatro concentrações diferentes de $\mathrm{CO}_{2}, 10,20,30$ e $40 \%$ foram testadas. No segundo experimento, a concentração de $\mathrm{O}_{2}$ foi fixada em $3 \%$ e quatro diferentes concentrações de $\mathrm{CO}_{2}, 3,6,10$ e $15 \%$ foram testadas. As flores foram colocadas em frascos de acrílico com de $20 \mathrm{~cm}$ x $80 \mathrm{~cm}$ de comprimento, conectada a um fluxocentro e receberam um fluxo contínuo de ar modificado. As taxas de gás $\left(\mathrm{CO}_{2}, \mathrm{O}_{2} \mathrm{e}_{2} \mathrm{H}_{4}\right)$ no ambiente de armazenamento foram determinadas utilizando amostras de $1000 \mu \mathrm{L}$ de ar extraído de cada frasco com uma seringa à prova de vazamento, as quais foram analisadas de cromatografia gasosa. A atmosfera controlada com $3 \%$ de $\mathrm{O}_{2}$ e $6 \%$ de $\mathrm{CO}_{2}$ a temperatura de $1{ }^{\circ} \mathrm{C}$ é indicada para o armazenamento de rosas.

Palavras-chave: dióxido de carbono, oxigênio, pós-colheita, fluxocentro.

\section{INTRODUCTION}

Brazil has prospects for being a producer and exporter of flowers and ornamental plants. The floriculture has been shown to be important in the economy and have a turnover of ca. R $\$ 6.5$ billion per year (JUNQUEIRA and PETTZ, 2017). However, significant part of the plant production investment can be simply lost if the proper attention to stages of harvest, handling and storage of the product is not correctly dispensed.

The maintenance of postharvest quality of cut flowers is highly important in order to guarantee the producer the expected income, thus sustain the in-place production chain. The postharvest losses can reach out $50 \%$ of the total

\footnotetext{
DOI: http://dx.doi.org/10.14295/oh.v23i3.1049

${ }^{(1)}$ Received in 13/06/2017 and accepted in 28/09/2017

(2) Instituto Agronômico (IAC), Campinas-SP, Brazil. *Corresponding author: glaucia@iac.sp.gov.br

(3) Instituto de Alimentos (ITAL), Campinas-SP, Brazil.

(4) Retired Professor FEAGRI- UNICAMP. Campinas-SP, Brazil

Licensed by CC BY 4.0
} 
yield. Thus, investing in postharvest handling can generate a more economically and environmentally viable return than to expand the production (DIAS-TAGLIACOZZO and MOSCA, 2007).

Among the several factors, that impact on cut flower quality after harvest, adequate storage and transport at low temperature is undoubtedly the most prominent one. Storage is responsible for maintaining the balance between the distributor and the consumer market and its goal is to maintain quality for commercialization. Cold storage is a way to delay senescence and consequently extend the product life span, since respiration and transpiration rates, as well as infections, are reduced (DIAS, 2016). The use of controlled atmosphere is complementary to refrigeration, thus capable of increasing the efficiency of refrigerated storage (AKBUDAK and ERIS, 2005).

Controlled atmosphere can significantly affect postharvest quality and marketability of cut flowers. The increase in $\mathrm{CO}_{2}$ concentration can be beneficial for product quality maintenance, being a reduction in the respiration rate the mostly observed effect (BURANA et al., 2013). An atmosphere of low $\mathrm{O}_{2}$ concentration can also reduce the respiration rate as well and maintain the flower quality (CEFOLA at al., 2016).

To the best of our knowledge, there are no studies relying on cold storage associated with controlled atmosphere (CA) for cut flowers in Brazil. Therefore, the establishment of appropriate postharvest storage technology under refrigeration and $\mathrm{CA}$ for cut flowers is important to the local flower industry.

The work aim was to define the ideal gas mixture ratio for cut roses 'Avalanche' under CA and cold storage, to generate exportation guidelines for CA use and to reach the end consumer with quality.

\section{MATERIAL AND METHODS}

Rose stems 'Avalanche' were harvested in the late afternoon and transported the following morning to the Postharvest Laboratory. The stems were divided into 20 random batches and placed in $32 \mathrm{~L}$ acrylic vessels, each vessel contained twelve stems. The vessel lid had 2 holes, one for the controlled air mixture entry and another to the exit, allowing the gas concentration adjustments. The gas mixtures were generated with the help of a portable flowboard made according to Calbo (1989).

Phase 1 experiment had stems stored at $21 \% \quad \mathrm{O}_{2}$ associated with 4 different concentrations of $\mathrm{CO}_{2}$, i.e. 10 , $20,30,40 \%$, the difference to $100 \%$ was supplemented with nitrogen. Both control and flowboards were kept in chambers at $1 \pm 1{ }^{\circ} \mathrm{C}$ for $7,14,21$ days. After each storage period, the batch of each treatment was withdrawn and transferred to $25{ }^{\circ} \mathrm{C}$ and $70 \% \mathrm{RH}$ for quality evaluations according to Dias et al. (2016), which included flower quality assessment, botrytis occurrence and foliage quality.

Phase 2 experiment had stems were stored at $3 \% \mathrm{O}_{2}$ and this time, 4 different concentrations of $\mathrm{CO}_{2}$ were used, i.e. 3, 6 and 10, and 15\%. Supplemented nitrogen was used to complete $100 \%$ and the experiment was for 7,14 and 21 days followed by CA conditions removal and quality assessment as previously mentioned.

The control samples in both experiments were subjected to atmospheric air after passing through solutions of $10 \% \mathrm{CaCl}_{2}$ and $5 \% \mathrm{KMnO}_{4}$, to remove $\mathrm{CO}_{2}$ and $\mathrm{C}_{2} \mathrm{H}_{4}$. Chromatographic analyzes were performed to certify the desired gas concentrations was enforced. The experimental design was completely randomized with 4 treatment replicates containing 12 stems.

The assessment was made by taking $1 \mathrm{~mL}$ samples from the vessel and injected into a Varian $3400 \AA$ Gas Chromatograph, equipped with a flame ionization detector (FID) and a thermal conductivity detector (TCD) for the analysis of $\mathrm{O}_{2}, \mathrm{CO}_{2}, \mathrm{~N}_{2}$ and $\mathrm{C}_{2} \mathrm{H}_{4}$ present in the sample. Column, injector, FID and TCD temperatures were respectively $80,120,250$ and $200{ }^{\circ} \mathrm{C}$, and the gas flows were $20 \mathrm{~mL} \mathrm{~min}^{-1}$ for the helium used as entrainment gas, $30 \mathrm{~mL} \mathrm{~min}^{-1}$ for hydrogen, $300 \mathrm{~mL} \mathrm{~min}^{-1}$ for synthetic air and $20 \mathrm{~mL} \mathrm{~min}^{-1}$ for TCD reference gas. The results of the metabolic activity of the roses were obtained in area and converted into mg CO $\mathrm{kg}^{-1} \mathrm{~h}^{-1}$ and $\mu \mathrm{L} \mathrm{C}_{2} \mathrm{H}_{4} \mathrm{~kg}^{-1} \mathrm{~h}^{-1}$.

The data was subjected to one way ANOVA and the means compared by the tukey test at 0.05 significance level with the help of SISVAR software (FERREIRA, 2011).

\section{RESULTS AND DISCUSSION}

\section{Phase 1}

The concentrations of $10,20,30$ and $40 \%$ of $\mathrm{CO}_{2}$ associated to $21 \% \mathrm{O}_{2}$ were not effective regardless of storage time. The weight loss was approximately $35 \%$ and no significant differences were observed between treatments. All treatments presented flower quality similar to those shown in Figure 1. The flower quality curves (Figure 1A) and the incidence of Botrytis cinerea curves (Figure 1B) were close to or below the control. The foliage quality did not exhibited significant differences between treatments and high $\mathrm{CO}_{2}$ concentrations showed a deleterious effect on the leaves (Figure 1C). 

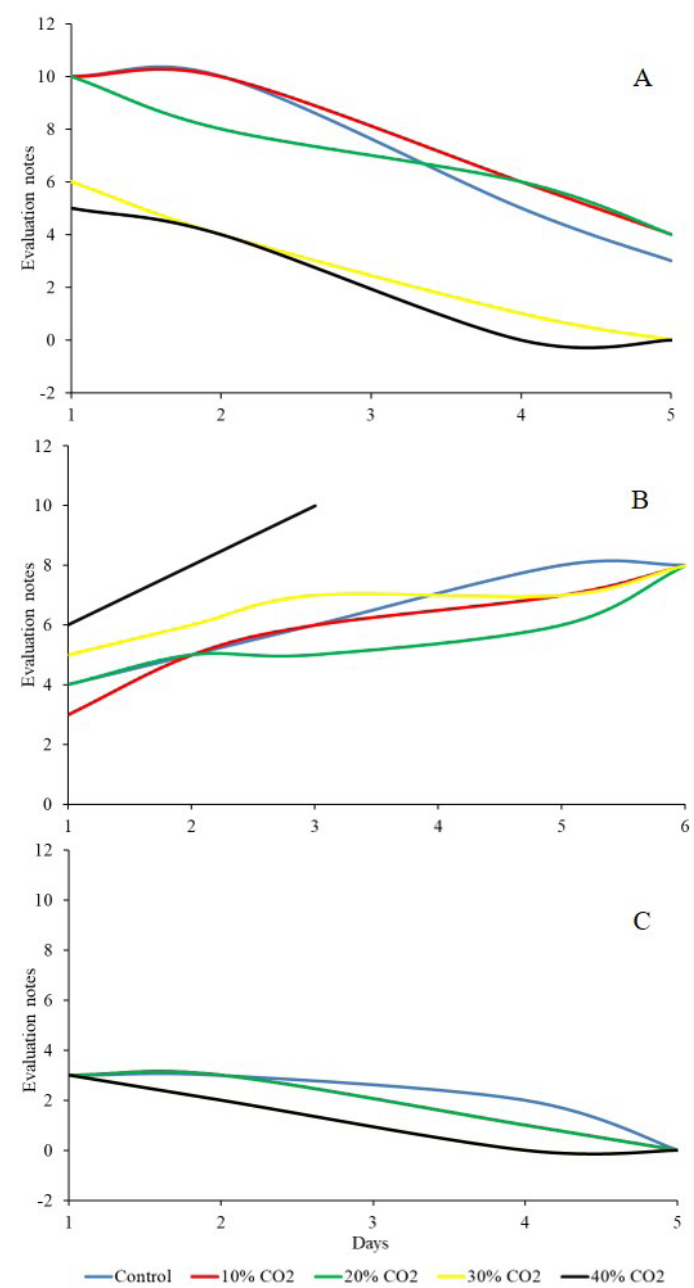

Figure1. Flower quality (A), Botrytis cinerea incidence (B) and foliage quality (C) of cut rose 'Avalanche' after being kept for 1 week under controlled atmosphere with $21 \% \mathrm{O}_{2}$ and $10,20,30$ and $40 \% \mathrm{CO}_{2}$ * ${ }^{*}$ (C) The $10 \%$ curve coincides with the values of $20 \%$ one and the $30 \%$ curve coincides with the values of $40 \%$ one.

\section{Phase2}

Considering that when using a CA with $21 \% \mathrm{O}_{2}$ associated with $10 \%$ and $20 \%$ of $\mathrm{CO}_{2}$ (phase 1 ) presented similar quality outcome to the control, and a detrimental effect of the $30 \%$ and $40 \% \quad \mathrm{CO}_{2}$ concentrations, the concentration of $\mathrm{O}_{2}$ was reduced to $3 \%$ and associated with the lower concentrations of $\mathrm{CO}_{2}$, i.e. $3,6,10$ and $15 \%$.
The results presented in figures 4 to 12 indicate that the best treatment was a $\mathrm{CA}$ containing $3 \% \mathrm{O}_{2}$ and $6 \% \mathrm{CO}_{2}$. The fresh weight loss, at this phase, was also around $35 \%$ and did not show differences between treatments.

After one week of CA storage (Figure 2), the effects of this treatment differs little from the others, including the control, and did not show significant differences between treatments. 

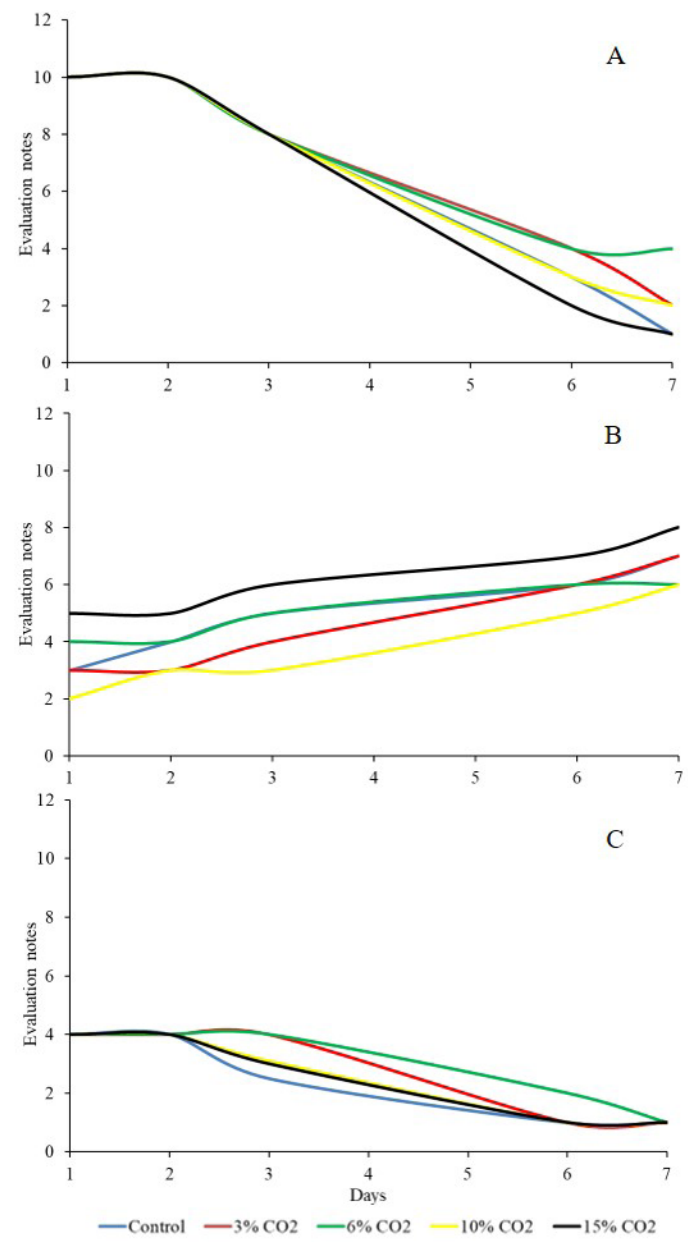

Figure 2. Flower quality (A), Botrytis cinerea incidence (B) and foliage quality (C) of cut rose 'Avalanche' after being kept for 1 week under controlled atmosphere with $21 \% \mathrm{O}_{2}$ and 3, 6, 10 and $15 \% \mathrm{CO}_{2}$.

Statistical analysis showed no significant differences $(\mathrm{p} \leq 0.05)$ between the treatments.

However, after 2 weeks (Figure 3) and mainly 3 weeks (Figure 4), there was a positive effect of the CA containing $3 \% \mathrm{O}_{2}$ and $6 \% \mathrm{CO}_{2}$ on the overall assessed quality when compared to the control.
This CA concentration was associates to higher flower quality, longer green foliage and minor Botrytis cinerea incidence, indicating that this is an adequate condition for cut rose storage. 

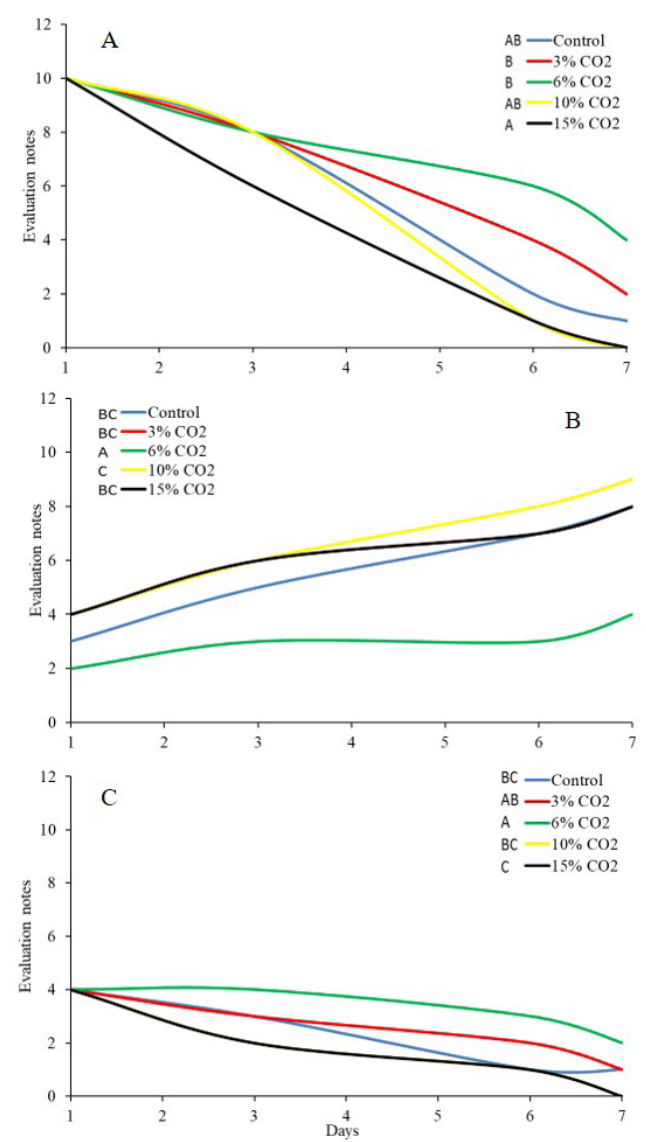

Figure 3. Flower quality (A), Botrytis cinerea incidence (B) and foliage quality (C) of cut rose 'Avalanche' after being kept for 2 weeks under controlled atmosphere with $21 \% \mathrm{O}_{2}$ and 3, 6, 10 and $15 \% \mathrm{CO}_{2}$. (C) Control and $10 \% \mathrm{CO}_{2}$ treatment lines overlap in the graph. Different letters indicate significant differences $(\mathrm{p} \leq 0.05)$ between the treatments. 

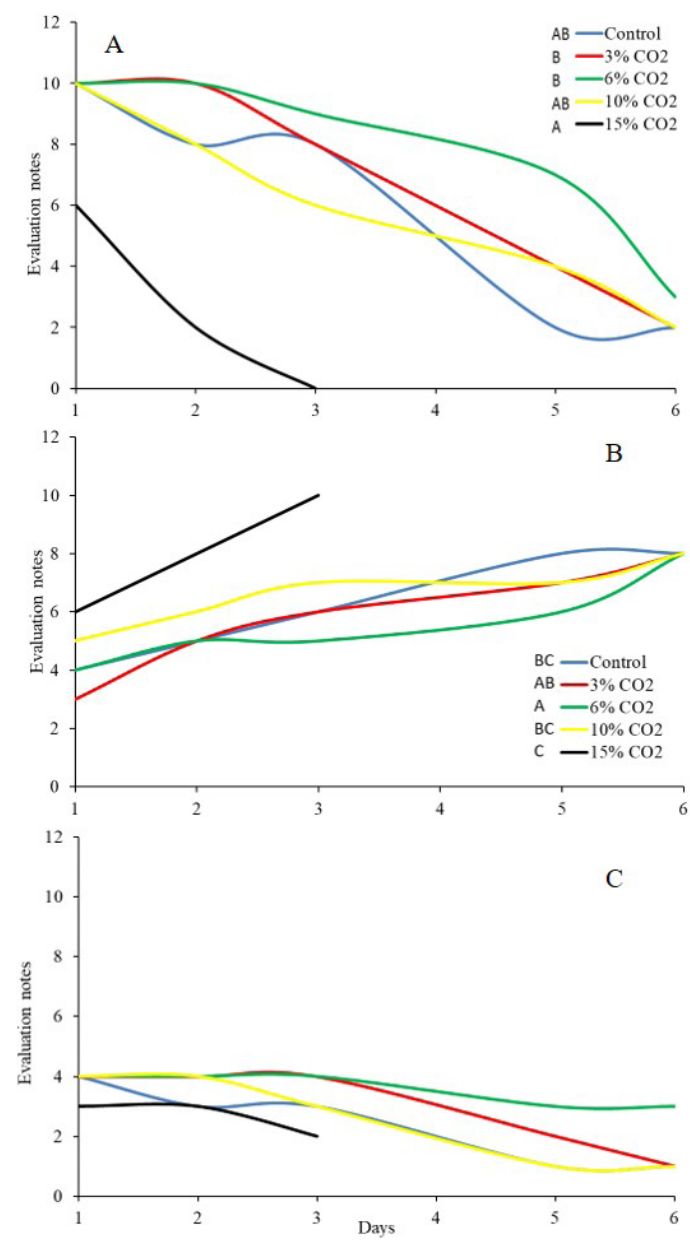

Figure 4. Flower quality (A), Botrytis cinerea incidence (B) and foliage quality (C) of cut rose 'Avalanche' after being kept for 3 weeks under controlled atmosphere with $21 \% \mathrm{O}_{2}$ and 3, 6, 10 and $15 \% \mathrm{CO}_{2}$. (A,B) Different letters indicate significant differences $(\mathrm{p} \leq 0.05)$ between the treatments;

(C) Statistical analysis showed no significant differences $(\mathrm{p} \leq 0.05)$ between the treatments.

\section{CONCLUSIONS}

The CA with $3 \% \mathrm{O}_{2}$ and $6 \% \mathrm{CO}_{2}$ at $1{ }^{\circ} \mathrm{C}$ showed significant quality maintenance for storage periods between 14 and 21 days and is suited for cut roses 'Avalanche' storage and could be used in procedures for the export of roses under controlled atmosphere.

\section{ACKNOWLEDGEMENTS}

The authors would like to thank FAPESP (grant $\mathrm{n}$. 2011/02555-4) for the project assistance; group Reijers for the flower stems donation and Bruno T. Favero for the graphics design.

\section{AUTHORS CONTRIBUTIONS}

GMD: Conduction and evaluation of the experiment in the laboratory; data management and statistical analysis; writing of the manuscript. LDGS: Conduction and evaluation of the experiment in the laboratory, data entries and statistical analysis. PC: Botrytis cinerea analysis and writing of the manuscript. JMMS: conduction and evaluation of the experiment in the laboratory. SLH.: evaluation of the experiment, statistical analysis, writing of the manuscript. 


\section{REFERENCES}

AKBUDAK, B.; ERIS, A. Normal and modified atmosphere packaging storage of lisianthus (Lisianthus grandiflorum) grown in saline conditions. New Zealand Journal of Crop and Horticultural Science, v.33, p.185-191, 2005.

BURANA, C.; KUROKURA, T. ; YAMANE, K. Shortterm controlled atmosphere and 1-mcp effects on the vase life of cut flowers. Acta Horticulturae, v.1071, p.635-639, 2013.

CALBO, A.G. Adaptação de um fluxocentro para estudos de trocas gasosas e um método de aferição de capilares. Pesquisa agropecuária Brasileira, v.24, n.6, p.733-739, 1989.

CEFOLA, M.; AMODIO, M. L.; COLELLI, G Extending postharvest life of ready-to-use zucchini flowers: effects of the atmosphere composition. Acta Horticulturae, v.1141, p.123-129, 2016. DOI: $<10.17660 /$ ActaHortic.2016.1141.13>
DIAS, G.M. Quality management of tropical plants. Ornamental Horticulture, v.22, n.3, p.256-258, 2016. DOI: <http://dx.doi.org/1014295/oh.v22i3.961>

DIAS，G.M.; SIGRIST, J.M.M.; CIA，P.; HONÓRIO, S.L. Armazenamento úmido e seco de rosas cortadas. Ornamental Horticulture, v.22, n.2, p.166-171, 2016. DOI: <http://dx.doi.org/1014295/oh.v22i2.912>

DIAS-TAGLiACOZZO, G.M.D., MOSCA, J.L. Póscolheita de flores e Folhagem. Revista Brasileira de Horticultura Ornamental, v.13, p.2009-2019, 2007. DOI: $<\mathrm{http} / / / \mathrm{dx}$.doi.org/1014295/rbho.v13i>

FERREIRA, D.F. Sisvar: a computer statistical analysis system. Ciência e Agrotecnologia, v.35, n.6, p.1039-1042, 2011.

JUNQUEIRA, A.H.; PEETZ, M.S. Brazilian consumption of flowers and ornamental plants: habits, practices and trends Ornamental Horticulture, v.23, n.2, p.178-184, 2017. DOI <http://dx.doi.org/1014295/oh.v23i2.1070> 